\title{
LUT
}

University

\section{Progress from Blue to the Green World: Multilevel Governance for Pollution} Prevention Planning and Sustainability

\author{
Awan Usama, Kraslawski Andrzej, Huiskonen Janne
}

This is a Author's accepted manuscript (AAM) version of a publication

published by Springer, Cham

in Handbook of Environmental Materials Management

DOI: 10.1007/978-3-319-58538-3_177-1

Copyright of the original publication: ( ) Springer Nature Switzerland AG 2020

Please cite the publication as follows:

Awan U., Kraslawski A., Huiskonen J. (2020) Progress from Blue to the Green World: Multilevel Governance for Pollution Prevention Planning and Sustainability. In: Hussain C. (eds) Handbook of Environmental Materials Management. Springer, Cham

This is a parallel published version of an original publication. This version can differ from the original published article. 


\section{Progress from blue world to green world: Multilevel governance for pollution prevention planning and sustainability}

Usama Awan, Andrzej Kraslawski, and Janne Huiskonen

\section{Contents}

Introduction

Multi-Level Governance

Supplier Engagement as a means to achieve sustainability

Environmental management capabilities as a means of Sustainable Development.......6 6

Leaders ecological behaviour on pro-environmental behaviour ............................... 7

Sustainable Marketing Practices as means to pollution prevention ............................. 8

Sustainable Consumption and Production as means of zero-pollution......................... 9

Circular Economy as a means of environmental material management ...................... 10

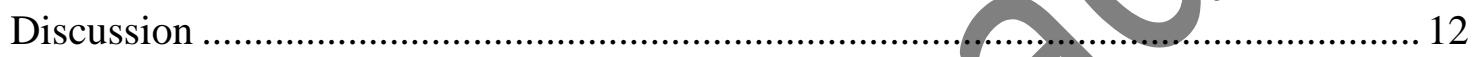

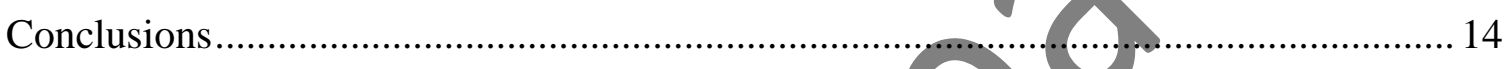

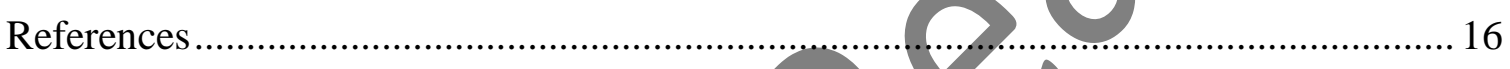

U. Awan $\left(^{*}\right) \cdot J$. Huiskonen

Industrial Engineering and Management, The Lappeenranta-Lahti University of Technology LUT,

Lappeenranta, Finland

e-mail: usama.awan@lut.fi; awan.usama@gmail.com; janne.huiskonen@lut.fi

A. Kraslawski

Industrial Engineering and Management, The Lappeenranta-Lahti University of

Technology LUT

Lappeenranta, Finland

Department of Process and Environmental Engineering, Lodz University of

Technology, Lodz,

Poland

e-mail:Andrzej.Kraslawski@lut.fi

Abstract

Pollution prevention is always better than environmental cure, and it is outlined that the issue of how pollution prevents emerging and is becoming an important pressing challenge in a contemporary globalisation world. Policymakers and practitioners increasingly recognise pollution prevention as a crucial global health issue. There is substantial agreement underlines the need to prevent pollution volume along with the manufacturing firms' operations. However, there is currently a lack of understanding as to what are most effective internal organisation governance practices to be implemented to achieve a zero-pollution target. Multi-level governance framework has been proposed to facilitate pollution prevention planning. To deal with the pollution prevention challenges, the practitioner must 
move towards more multi-level governance approach that builds on a grand coalition of different organisational units. In the current study, we review relevant literature, noting most optimal taxonomies that highlight understudied areas in pollution prevention study, and serve as a basis for developing multi-level governance(MLG) framework. MLGframework is essential not only it offers help to practitioners to participate, but also because it takes a systematic approach. This work contributes to the emerging debate on what is the most effective pollution prevention planning framework for manufacturing firms to achieve zeropollution.

\section{Keywords:}

Pollution prevention- global health issue- zero-pollution-multi-level governance-pollution prevention planning

\section{Introduction}

Environmental pollution (air, soil, water and chemical) is of considerable concern in industrial systems and have widespread effects on human health.it is becoming a challenge for the industries if firms continue to consume the material at the current rate. Pollution and climate change challenges will play a key role in the move towards a more sustainable world for future generations. As the impacts of pollution increases, due to unsustainable practices increase. For manufacturing industries to fully contribute to the transition towards the green world, multi-level governance mechanisms needed to be integrated into the core sustainability practices. The transition from minimum integration of ecological practices ( blue world) to maximum integration of ecological practices(the green world) requires creative ways of multi-leyel governance mechanism that involves a range of sustainability practices within the boundaries of organizations. The blue world is the simultaneous pursuit of economic gains using environmental prevention strategies. It is about capturing a new market space, thereby making greater profits. Blue world concept is based on the view that environmental boundaries and market dynamism are not considered and can be recreated by the innovative process of industrial players.

In contrast, green world, industrial sector creat demands of the environmental concern, the pursuit of financial gains, and visualize the world as connect humanity and nature leading and maximum integration of ecological practices. Green world denotes that the industrial sector continues pursuit of economic and environmental gains as well as focuses on social gains. It emphasises a system thinking approach, which is the blueprint for clinching a more acceptable and maintainable sustainable future for all. For humanity, the green world is a crucial mean to create new consumption patterns to sustain ecological growth. The environmental material management is an evolving field which has facilitated the development of cleaner production technologies and has opened up opportunities for manufacturing industries. The multi-level governance of the hazardous material impact on environmental and human is part of a growing body of research in environmental science and material management. 


\section{Background}

The importance of sustainability application in the production process has attracted the attention of practitioners and researchers in different fields, and its impact has grown increasingly over the last decades (Carter and Rogers, 2008). The use of cleaner production technologies and economical methods can minimize smog (Zhang, Liu and Li 2014). Recently, smog has become one of the greatest challenges in emerging countries (Zhang et al., 2014). According to (Landrigan et al., 2018), pollution is a major source of diseases and deaths. Pollution is unevenly distributed throughout the world. The smog is arising due to the high levels of poor air quality and pollution; the main source of this problem is polluted industries. The community lives near these factories are forced to wear mask outdoor. A more recent report found that air pollution has caused 4,400 deaths a year in Pakistan (Kumar, 2016). The outdoor air quality can have a positive impact on the human health, and smog causes acute diseases such as chronic respiratory and asthma diseases and especially cause increased mortality in China (Lu et al., 2015). Smog is the combined result of local climate conditions and the result of human activities and threatening sustainable development globally (Zhang and Samet 2015). One in every four death in the world is due to pollution). Air pollution leads to rising death tools each year, and water pollution is responsible for 0.8 million people deaths(Landrigan et al., 2019). Although pollution and fear of climate change can have a dramatic and catastrophic effect on human's everyday lives. Today, there is no lack of literature questioning the relative effectiveness of preventative measures of toxic chemical pollutions. Environmental pollution is rooted in the use of toxic chemicals by manufacturing firms. (Landrigan et al., 2019) provide a hypnotic overview of how low-income countries have greater exposure to toxic waste due to globalisation. In current academic literature, specific attention is given to issues related to sustainability due to the advent of the recent environmental globalization issues, and pressure from, international regulatory bodies have promoted the environment material management and marketing researchers to pay attention towards sustainability issues as a topic of inquire(Chabowski et al., 2011). For example, South Asia region particular lack of an effective legal system to guard against unethical corpthe orate behaviothe ur (Bthe ai and Chang, 2015). Due to intensive competition and justification of the problems relating to the natural environment many firms in the world are adopting sustainable marketing practices (Leonidou, Katsikeas and Morgan, 2013). Firms response to these challenges is taken into account from their ethical standing of reducing the hazardous effect of the environment on humans (Carballo-Penela and Doménech, 2010).

(Landrigan and Goldman, 2011)find the absence of safety policies requiring that manufacturer must test chemicals for the safety before they are a license to launch products in markets. It is therefore essential that chemical manufacturing industries properly take responsibility that the product they produce is free from any hazardous toxic impact, As the absence of the of health and occupational regulations, almost seventy per cent of chemical manufacturers are located in developing countries(Landrigan et al., 2019). For example, Matell, a China-based manufacturer of toys, had prepared it with lead paint (Tang, 2008).In another case of Sodexo, contaminated frozen strawberries caused an outbreak of disease E.coli among the school children's in German (e.g., Leppelt, Foerstl, Reuter, \& Hartmann, 2013). In Parallel, European Union are increasingly implementing the new regulations 
Registration, Evaluation and Authorization of Chemicals (REACH) reporting by the firms towards attempting to protect the social issues such as( human health) (European Commission, 2007). There are glaring benefits for the ecological system to prevent pollution. According to environmental protection agency(EPF) define pollution prevention, "source reduction and closed-loop recycling are considered to be the most viable pollution prevention techniques, preceding treatment and disposal"(United States Environmental Protection Agency., 1992). Many prior research emphasize the noteworthiness of different determinants to pollution prevention such as , Culture and organization learning, (Roy, 1992) law enforcement (Jiang et al., 2014), Effect of environmental capabilities on pollution prevention and cleaner production system (Bae, 2017), circular economy (Sousa-Zomer et al., 2017). Despite the importance of corporate sustainability practices influences on minimising environmental pollution in the production process is remain limited. In summary, the literature shows that pollution increased through most of the 21 st century. The manufacturing industry is a source of major environmental damage, waste release within the production facility contribute directly or indirectly to the contamination and pollution. The release of waste is directly associated with the emanating human health problems from drinking water, air pollution. What is still missing at the organizational level and what has not been taken into account are the increasing developing strategic measures of preventing environmental pollution. One of the key challenges manufacturing industries face about environmental pollution sustainability is its implementation of strategic vision.

However, there has been less research focused on identifying the competency areas within manufacturing or production capacity. The manufacturing sector has attracted the attention of media and academics for international pollution prevention and its applications in the development of new product and as well as the use of process technologies. But it is difficult for the export industries to understand how to acquire a better level of understanding of firm activities and learning process. It is called for to focus on development on the new technical capabilities, acquire new knowledge and skills. It is evident there is an increase in the environmental and air pollution from manufacturing industries is due to a lack of advancement in the technology and entrance of new competitors in the market. Pollution prevention is always better than environmental cure, and it is outlined that the issue of how pollution prevents emerging and is becoming an important pressing challenge in a contemporary globalisation world. This challenge is in part driven by an enlarged understanding that existing approaches focus on what manufacturing firm do after the hazardous impact of pollution are reported, inevitably fail to address situations. Although, the literature on the causes of pollution emerges from an operations literature that does not helpfully inform clear pollution prevention planning. Accordingly, there is some emerging practice in the field of pollution prevention, but still, practitioners have some progress to make to achieve zero-pollution targets.

\section{Emerging patterns of pollution prevention governance}

In comparison with other sustainability areas of sustainable development, pollution prevention has, therefore, has appeared in a much unrushed and more steady than other climate change issues. Indeed, material management remained a little eye-catching spot reinforced by a mix of an industrial climate action plan for pollution prevention. 


\section{Supplier Engagement as a means to achieve sustainability}

The triple bottom line concept proposes (Elkington, 1997) takes into account environmental economic and social dimensions into decision-making. Scholars in sustainability have shown interest in how civic sustainability affect firm sustainable development performance (Awan et al., 2014). The concept of sustainability has emerged as a complex and multidimensional issue and widely recognized as a central organization need for survival of business in the competitive world(Vinodh and Girubha, 2012). The organization sustainability is based on a triple bottom line (TBL) approach, environmental, economic and social equity; which has emerged as to tackle the environmental issues such as biodiversity, saving energy and decreasing the use of material consumption requirement and climate change (Elkington, 1997). There is yet no consensus on sustainability definition but generally, define "as using resources to meet the needs of the present without compromising the ability of future generations to meet their own needs" (Brundtland and Others, 1987). Myriad discussion on the sustainability issues are concerned with improving performance and are associated with sustainable development. The Sustainability and Sustainable Development term has been used interchangeably in the literature (Aras and Crowther, 2009). Since the inception of the sustainability concept in the 1980s, debates on the application of sustainability and sustainable development have grown over the last decades and continues about civic sustainability and circular economy.

Buyer-driven knowledge transfer practices are considered pivotal approaches to improve supplier capabilities (Modi and Mabert, 2007). Buyer-supplier relationship research has examined the impact of supplier development on sustainability performance( e.g., (Kumar and Rahman, 2016; Mani et al., 2018). Previous studies suggested that knowledge base resources are critically important to firms developing a new process (Li et al., 2017). Moreover, (Wagner, 2010) considered both direct and indirect efforts results in lowering the supplier performance due to ambiguity and lack of clarity for goal achievement. Specifically, the implementation of environmental and social standards requires the interaction of customers and suppliers across the operations. We specifically consider the role of social factors play in supplier development relationships as buyer-driven knowledge practices have been successful in improving supplier performance (Modi and Mabert, 2007). Industrial ecology requires firms to cooperate more closely to realise its promise of increasing environmental benefits(Korhonen et al., 2018).

As a result, culture has also demonstrated their contribution to foster social cohesion, protect and understanding between the buyer-supplier, and enhance the inter-firm collaboration(Awan et al., 2018a). The concept of supplier social engagement has taken by (Reuter et al., 2010), where they discussed the case of two firms and highlighted the buyer viewpoint on supplier importance. One of the company representative highlight that, "Together with our supplier s, we seek to ensure that applicable laws are complied with and working conditions and environmental protection measures are improved across our supply 
chain. In doing so, we improve relations with our supplier and raise our attractiveness to increasingly ethically-aware customers and financial markets', , buyers across different countries have begun to stress the importance of developing supplier in understanding their needs on social issues and the development offerings to create a responsible, sustainable performance. At an operational level, the benefit to a supplier to supplier developing a close relationship with key buyers comes in the form of improving infrastructure, develop new process and procedures, reducing environmental impacts of operations lead to sustainable performance improvements.

Supplier to supplier (S2S) supplier engagement on sustainability is a key aspect of sustainable development and is a means to ensure sustainable performance in the supply chain. A central challenge for buyer firms is how to govern the relationship with suppliers to foster supplier commitment to sustainability (Sancha et al., 2016b). Specifically, (Saunders et al., 2015) demonstrate how sustainability outcomes are impacted by supplier integration in supply chain management. The supplier firm sees buyer engagement offers an opportunity to joint problem solving, development of human capital and infrastructure, coordination and resource building activities for the pursuit of common performance objectives. Supplier engagement approach with buyers included knowledge combination, identification and assimilation mechanism to integrate external sustainability knowledge and jointly develop sustainability practices (Meinlschmidt et al., 2016). The supplier engagement here means commitment, motivate to collaborate to meet the applicable regulations, working conditions and environmental protection across the supply chain. Operational methods are included such waste management practices (recycling of material, waste exchange and work arrangements for resource conservations. (Sancha et al., 2016a) emphasis the fact that buyer-supplier relationship results in increased knowledge and better sustainability performance(Leon-Bravo et al., 2017). The core supplier to supplier (S2S) and buyer-supplier engagement function is to explore new opportunities in achieving desired results. The buyer provides resources in the form of knowledge, skills and technology to improve the supplier firm knowledge and skills that are necessary to cope with the social sustainability initiatives. In this study, supplier engagement is referred to as, the ability of supplier firm to participate constructively to the social practices and aspects of suppliers to create more sustainability performance and sustainable communities. I argue that supplier engage reflects a firm capability in acquisition resources and deploying, usually in combination, to achieve pollution performance. Supplier engagement in an inter-firm relationship can understand the extent to which the firm involved and making the possible effort to solve any problems that arise during cooperation. It promotes collective initiatives and policies that aim to incorporate the analysis of social impacts associated with supply chain management.

\section{Environmental management capabilities as a means of Sustainable Development}

The need for sustainable practices is becoming more important as the new challenges in achieving cost-effective manufacturing, particularly, reducing energy consumption and waste management (Boiral, 2006). The design of a product should use environmentally 
friendly materials and components to be disposed of and can easily recycle after use. The design of the product should also include recyclable and biodegradable material (Kenneth W. Green Jr. et al., 2012). A few studies have considered organisational environmental management capability for control of natural resource consumption (Linton et al., 2007; Parmigiani et al., 2011). Regulations in large manufacturing firms encourage adopting ecodesign practices and use of recyclable material and reusable parts. The objective of the adoption of green practices includes eliminating pollution from processes, minimizing waste material, waste treatment, reduction of energy consumption, compliance of regulations, the attraction of customers and cost savings. The term ecological design in this present study will focus on using various analytical tools and methods to adopt environmental practices at different stages (Deif, 2011). This represents the best way to bring a range of resources and capabilities beyond those of the firm to solve the complex problems that sustainability presents for the firm (Formentini and Taticchi, 2016).

For pollution prevention measures,eco-efficient practices and approaches in the manufacturing process to minimize the environmental footprint through the handling of raw material, waste management, transportation and packaging. Internal activities of the firm are essential to for environmental protection from an international business perspective such as the development of the remanufacturing process and managing physical flow with ecoefficiency(Guide et al., 2003). The results suggest that a firm can eliminate source reduction in changing its product or process design and through use of greening strategies. Our literature highlights the various types of environmental management capabilities are essential components of the stages of sustainable performance improvement. We suggest that it look very tough for practitioners to know, how to enhance, what to do to commence best practices, assessing and contribution to sustainable development.

\section{Leaders ecological behaviour on pro-environmental behaviour}

(Ones and Dilchert, 2012) refers to green behaviours as "scalable actions and behaviours that employees engage in that are linked with and contribute to or detract from environmental sustainability" (p. 87). Lack of organizational support is considering a significant hindrance in green work behaviour (Zibarras and Ballinger, 2011). In export manufacturing firms, where most of the relationship is managed with the contract or relational governance have to influence their partners, who routinely use their requirements, to include social performance initiatives as part of everyday supply chain practices( Awan, Kraslawski, \& Huiskonen, 2018a). The following main behaviours are included conserving (i.e., reducing use, reusing, repurposing and recycling), influence others (providing information, encouraging the use of eco-friendly working habits, changing how work is done, initiating gree-policies and initiating). Several research studies can be found that mainly focused on household behaviour.

Whereas the research in Organization behaviour that deals with the employee's workplace, pro-green behaviour is scarce (Russell and Griffiths, 2008). Despite these research studies and initiatives, there is a dearth of research studies related to the organization and proenvironmental sustainability (Jackson and Seo, 2010). (Podsakoff et al., 2014) suggested future studies should focus on examining the effects of organization citizenship behaviours 
an outcome measure of efficiency and waste reduction. (Lambert, Cooper \& Pagh, 1998) Suggest the leadership style as an approach at the firm level is necessary to coordinate the efforts of multiple supply chain partners that may overcome the problems. The question raises here, what leadership styles may influence the social sustainability performance of the firm. Social performance is increasingly being portrayed as an opportunity for enhancing supply chain performance (Mani et al., 2018), while some also consider it as win a win situation being socially responsible towards individual and society (U. Awan et al., 2018) For example, a study by (Fehr et al., 2015) explored the connection between leadership style and performance, finding a positive association. The transactional leadership behaviour integrative supply chain concern is vital for the firms competing for strategically sustainable development performance. Thus, by employing recent works on governance mechanism effectiveness on sustainability performance (Sancha, Gimenez, Sierra \& Kazeminia, 2015). For example, Great Thunberg is a Swedish youngest climate movement activist, and have participated in the rise for climate demonstration in different parts of the world.Her enthusiatic and pro-environmental protection behaviour mobilising the number of young people to start thinking about the environment.I have identified three important roles of the ecological leadership are suitable for the supply chain process, seek different perspectives when solving purchasing problems, clarify the central purpose-and talk enthusiastically about what needs to be accomplished. Thus, leaders who motivate and pay attention to clarify the central purpose, talk enthusiastically and seek different perspectives when solving problems can, therefore, have an impact on firm social performance.

\section{Sustainable Marketing Practices as means to pollution prevention}

Green or environmental or sustainable marketing has been recognized a visible force towards sustainable development and defines as "the holistic management process responsible for identifying, anticipating and satisfying the requirement of customers and society, profitably and sustainably"(Peattie and Belz, 2010). Green marketing has been viewed as to adjust existing organizational and environmental related objective to prevent waste and meet consumer expectations. However, it can be seen as the firms such action as responsiveness to the environmental related demands for eco-related product and services design, consideration of greening prices, eco-related practices in logistics and green communication strategies. Green refers as (eco-marketing, environmental, ecological or sustainable) marketing and defined "policies, practices, and procedures in the realm of marketing that explicitly incorporate an ecologically-friendly focus with the goal of creating revenue by providing exchanges that satisfy organizational and individual objectives for a product and/or product line (Menon and Menon, 1997). Green marketing practices affect environmental in two ways. First, reduce the use of resources in new product development. Many manufacturing companies invest resources in finding ever more innovative ways to reduce waste and pollution. Second, reduce material cost by reusing the material, which ultimately decreases pollution(Awan, 2011).

The firms sustainable marketing programs are centred focus on marketing mix (1) Products., changes in the actual and augmented attributes of a product to show ecological benefits;(2) by viewing the benefit to be borne by the society but through in terms of higher prices and advantage;(3)distribution channel, to develop environmentally friendly activities or devise appropriate product after use arrangements;(4) promotion activities by focusing on 
informing customers through communication mix about the green activities(Polonsky and Rosenberger III, 2001). Environmentally friendly products play an important role in pollution prevention. The success of the green products mainly depends on the understanding of the pro-environmental consumer behaviour and developing the marketing mix that satisfies and meets the needs and satisfy their wants more effectively than competitors (Peattie and Belz, 2010). The above discussion shows that adding environmental benefits into products and services provides many opportunities to the companies including effective use of resources, a substantial increase in sales, development of the new market, product differentiation and improved corporate image (Dangelico and Pujari, 2010). In this respect, it is important for the marketer and management to study and determine the most important factors that create constraints in the adoption of green products. Thus, it has become very important to identify the significant factors that constraints innovative consumers to adopt the eco-friendly(green) products. Despite the crucial influence of green marketing practices and increasing interest in examining the product, pricing, distributions and promotion aspect have provided more opportunities than others (Leonidou et al., 2013). They also suggested that firm green promotional and pricing strategies positively correlate with the increase in sales.

\section{Sustainable Consumption and Production as means of zero-pollution}

The research on environmental consciousness and pollution prevention and its attributes have been very famous among the researchers, and a wide range of literature is an exit, which focused on pro-environmental behaviour, and few studies found in the consumer's decision-making process related to the sustainable consumption and production behaviour. European Union (EU) has set target to achieve energy efficiency as a part of the climate and energy package to reduce the impact of greenhouse gas emissions and efficiency gain in the use of renewable energy at households (European Commision, 2012) Household sector is key to determine whether EU meets the objective to save energy or not. The pollution prevention target could be achieved through the adoption of better energy efficient technologies and energy savings practices. Adoption of household energy efficiency and conservation practices are rather scared and have been concentrated in the USA, Canada and severah individual EU countries. The zero-waste approach includes sustainable design, producer responsibility, as well as reduction, reuse and recycling of waste (Murray, 2002).

Sustainable consumption seeks to both decrease the levels of consumption and limit the consumerist thirst for further possessions (Karlsson and Luttropp, 2006). The concept of green consumer behaviour underlays all the consumption and production patterns change articulations of sustainability(Awan and Raza, 2010).

Decision making must be based on looking at new material management practices for the future generation, looking for alternative use of materials and encouraging sustainable consumption and production behaviours. Consumer decision making process is constructed as 'basic consumer personality' and can be defined as "a mental orientation characterizing a consumer's approach to making choices"(Sprotles and Kendall, 1986). In order to encourage the consumer to buy the green or sustainable product, corporations required to deliver clear and pertinent information about their products through labelling and 
packaging(Awan, 2011) Consumer will like mostly to favour those corporate products which are actively participating in reducing the carbon footprint. Corporations that involve in societal programs and have developed their image as social responsibly are more likely to influence the consumer when they make the purchase decision and willingness to pay more for the sustainable product.(Awan and Raza, 2010). The results of (Awan and Abbasi, 2013) study shows that the socio-demographic characteristics significant impact in intentions to use and attitude to adopt the product. Consumer socio-economic status significantly influenced varied statistically. (Kleijnen et al., 2009) The support that the economic factors are the main motives to postpone the decision of adoption of new products or perceived existing usage patterns is incompatible with social norms.

On the other hand, a consumer who rejects to adopt the innovation believed that it might cause a negative image. (Nyrud et al., 2008) noted that "subjective norms" has a positive effect on consumer willingness and intention to use green energy. Although, many researchers have begun to investigate how firms can improve the process development and marketing strategies to improve their product performance to overcome the consumer resistance towards green products(Antioco and Kleijnen, 2010). Since the emergence of electronic media for advertising, direct mailing and updated information available on goods and services stimuli the consumers to buy and further intensify the decision-making process. According to(Kaiser et al., 2005) Attitudinal theories has been referred as (a) the valuebelief-norm (VBN) theory focused on moral norms; and (b) the theory of planned behaviour (TPB) focused on rational and self-interest based (Ajzen, 1991). Theory of reasoned action (TRA) has its roots in social psychology and utilized in the formation of attitudinal. These models widely used to anticipate consumer satisfaction with the product which determined by the belief and value of product fulfil certain needs and wants. TRA suggests that intention to adopt or evaluate the consequences of alternative behaviour depends on a person's attitude of the product or his subjective norms. Other studies, therefore, have suggested that attitudinal behaviour context model (ABC) and Needs opportunity ability model (NOA) (Gatersleben and Vlek, 1998)conceptualise the personal and contextual factors on consumers. For example, models like NOA, are generally complex to be tested because this suggests that consumer motivated when the product is available. Many other researchers have, therefore taken different approaches.

\section{Circular Economy as a means of environmental material management}

Circular economy concepts are trending both practitioners and scholars to link circular economy practices to the concept of sustainable development(Murray et al., 2017). The concept of the circular economy was initial regulated and being implemented in China. The circular economy concept currently promoted by Ellen Macarthur Foundation and rapidly accepted by the EU and by several national governments including the United Kingdom, France, Japan, China and especially in Finland. The word circular related to the concept of cycle and economy in terms of production and consumption of two cycles, (1) biogeochemical cycles and (2) idea of recycling of products(Murray et al., 2017). The idea of the circular economy has been expressed by 3r,4R framework, reduce, reuse, recycle and 
recover (Kirchherr et al., 2017). The 4R framework as the ' how-to' is at the course of the European Union water framework direction (European Commission, 2008). The circular economy is defined as, "an economic model wherein planning, resourcing, procurement, production and reprocessing are designed and managed, as both process and output, to maximize ecosystem functioning and human well-being" (Murray et al., 2017). The circular economy is emerging as an economic strategy, enables system thinkings(Korhonen et al., 2018), looking for "closed loops" (Bocken et al., 2016) emphasize on the reuse remanufacturing, refurbishment through-out the product value chain and cradle to cradle life cycle.

Of the material used for battery, lithium is nontoxic, very light electropositive and widely available. These characteristics of lithium allow batteries to have a higher potential for power storage (Zubi et al., 2018). Embedding circular economy principles of reuse, remanufacturing and recycling is seen as one method to minimize production cost and environmental impact(Groenewald et al., 2017). The recycling of Li-ion batteries for recovering the lithium and other materials has been studied by(Zeng et al., 2014) The collection of waste and recycling programs is the right path towards sustainability(Gonçalves et al., 2016). Critical materials such as lithium represent a supply disruption risk, that shift focus of practitioners towards alternative materials and use fo circular economy concepts, such as reuse and remanufacturing could reduce the need for virgin material (Zubi et al., 2018). Lithium can be produced from the hard rock resources with the richest hard-rock resource countries are Finland, Canada, China, Australia, Serbia and Mexico(Zubi et al., 2018).

Reuse and remanufacturing economy mode in the firm may emphasize some investment in the collection of the end of life products from customers. Circular economy may have some industrial links with different suppliers. In this way, the firm can establish a recycling factory for the production of products with the circular economy approach. This re-use of material will bring more component into the remanufacturing loop, enabling the material to recycle and optimization potential for further decrees energy consumptions and material input cost. A 21Ist century, the economy would not be possible without a reliable process of reverse logistics of waste to support pollution prevention measures. A circular economy is an industrial system could be seen as a system that integrates the economy with ecological consideration design and proposing a completely different way of resource utilization. I argue that the implementation of the circular model for the firm is key to cost and zeropollution as they seek continuously to improve and sustain their business models. The establishment of recycling plant into its current business model led may lead to firm rethink on upcycling and redesign existing business models, to better collaborate, engage with their customers and suppliers, while creating an advantage for the end users (customers). For example, the during recycling process (refurbish process), the firm can create another new product for a new market aimed at support zero-pollution. The advantage of this redesigned model may develop better and value appropriation relations with different stakeholders to include more service-oriented recycling process. The focus on the circular economy model may help the firm to moves away being a zero-pollution firm in the market. 


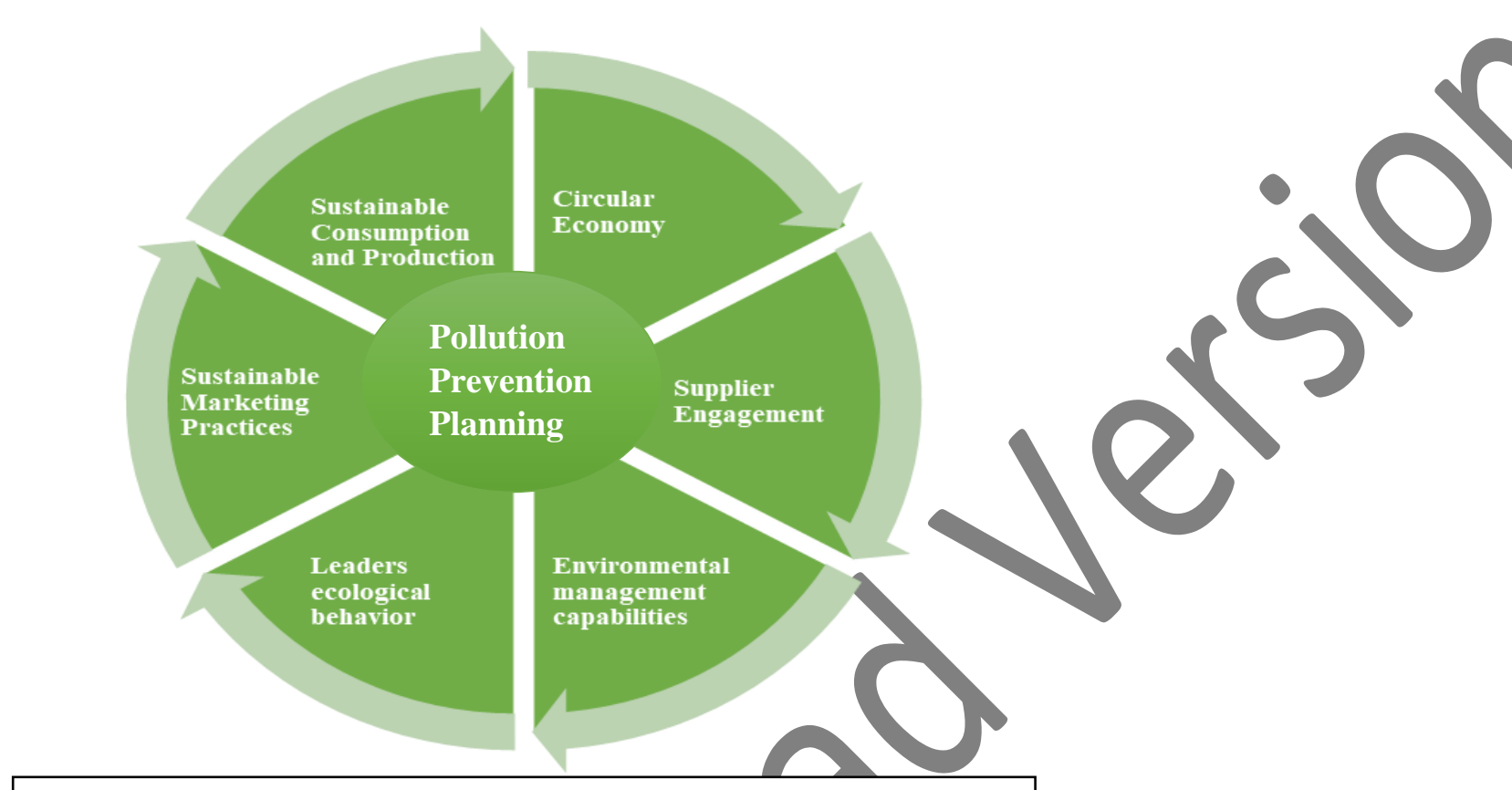

Fig.1 Governance for 3P( pollution prevention planning)

\section{Discussion}

Pollution prevention planning goes through a series of steps making up an on-going planning process. The six-phase model is summarized in figure 1. The idea of supplier engagement to involve on responsible sourcing and to ensure the material is used to create environmental value for the firm, lower waste and minimize greenhouse gases impact. Supplier engagement process deals with the exchange of information, knowledge resources, collaboration for green and clean sourcing supply of materials in primary activities of value chain analysis(see for details (Porter, 2011). In this phase, it is important to deliver responsible sourcing practices. Another important multi-level governance process is environmental management practices. The idea of environmental management capabilities to safely manage the material during the processing and finishing at the production level. It is the ability to develop a system that has considerable value for addressing $\mathrm{CO} 2$ emissions and minimize environmental pollution. It required a varied degree of competencies, in the product life cycle stage at the level of process and product to ensure and improve pollution performance. Ecology leadership style may also affect the industries to achieve zero-pollution. Ecological leadership style is important in developing pollution related awareness, formulating and executing pollution related programs within the boundaries of the firm. The multi-level governance framework is depicted in figure 2.

An organization capability for pollution prevention measures is often determined its overall sustainable industrial marketing programs. Manufacturing firms must have a sustainable marketing program, and the firm must be able to respond effectively to the partner's environmental needs. Sustainable marketing can forecast accurately long-term marketing 
mix development. The importance of sustainable marketing approach is to facilitate the organization process towards zero-pollution. Sustainable marketing is the most powerful tool to support preventive pollution measures in making a more rational choice in consuming material while meeting the environmental needs of customers and consumers.

Similarly, the sustainable consumption and production need to be fully integrated as means to achieve a current business position, that is, keeping up the pace of sustainable development initiatives and ensuring that materials are consumed less as compared to the previously developed products. It will enhance the judicious use, produce and consume of materials to preserve green and clean environment for the future generation. Despite increasing recognition of greenhouse gases impact on human and environment, mainstreaming of the circular economy for pollution prevention at firm level remains a significant factor to support sustainable development.

In the firm, activities have two sides. On the one hand, primary activities and supporting activities(Porter, 2011) Value chain analysis has a long-standing contribution to play a significant role as a change agent in firm operations. Firm operations form up stram and downstream has had to develop many practices at the same time, to promote the kind of saving planet from brinkmanship, which is such a hallmark of pollution prevention policy. The key issue is here is not why value chain analysis changed, but how it promotes through key sustainability initiatives to achieve pollution prevention targets. Multi-level governance (MLG) characterizes the mutually dependent relationship can be regarded as vertical and horizontal among the firm primary and supporting activities of value chain aimed at zeropollution.MLC can also be regarded as an effectual platform in which over time; multiple sustainability practices may contribute to making it possible for the manufacturing industry to sustain a zero-pollution agenda. The vertical and horizontal multi-level governance structure of the firm value chain activities makes it possible that pollution prevention initiative takes place at different parts of the value chain. These sustainability initiatives can also be adopted in other units of the firm operations. Manufacturing industries and other related industries could wield their zero-pollution agenda setting the vision, developing and boosting new pollution prevention policies.

At the primary and supporting level of activities, a wide variety of opportunities can be observed. Supplier engagement, at the inbound logistics level, firm infrastructure, technology development, human resource management and procurement can be a source to transfer their share to achieve pollution prevention targets. Similarly, it can be useful for procurement and all primary activities from inbound logistics to services. Especially for firm infrastructure, supplier engagement becomes necessary for outbound logistics, marketing and sales, and services. Similarly, other sustainability initiatives interaction with different primary and supporting activities might provide condition to support zero-pollution policy. 


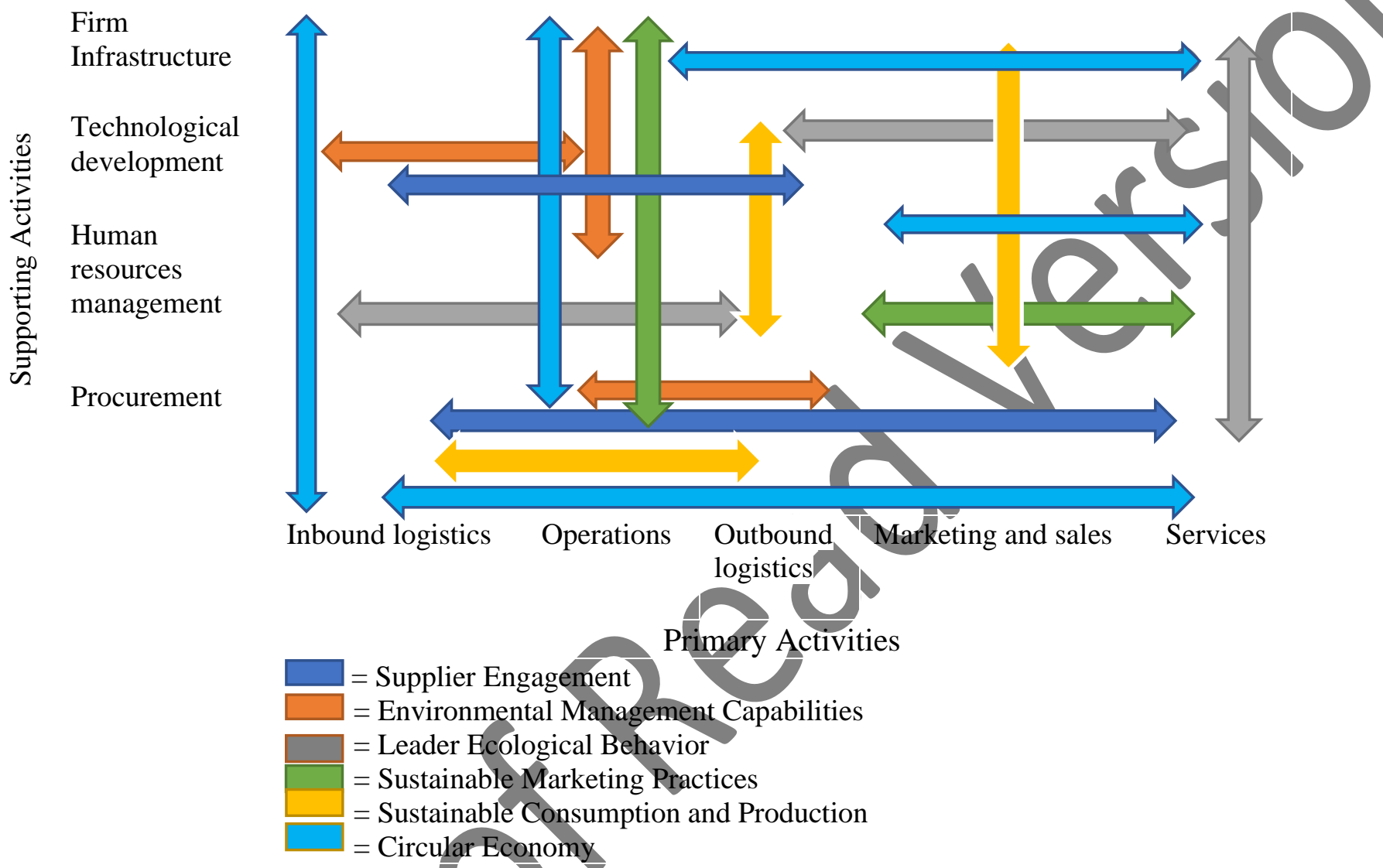

Fig.3 Multi-level governance framework

\section{Conclusions}

The zero-pollution development practices and re-use of material are considered to be important penetration strategies for manufacturing firms. Environmental material management has been adopted as a strategic tool to show that material management governances are good predictors of zero-pollution targets. Environmental material management practices are complex and diverse, multi-level governance(MLG) mechanism helps a firm identify new practices, generate new information about good practices, and cleaner production technology. Pollution prevention planning often too complicated to be dealt with one decision fits well to achieve better pollution measures.MLG is a set of many interacting organizational unites different practices that enables to design and implement practices across the firm (shown in figure 2). Zero-pollution policy has emerged as a foremost focus of research among practitioners and academicians as well as international institutions who are seeking to understand pollution prevention governance.MLG governance emphasis on diminution as opposed to adjustments and reliance on multiple integrated sustainability initiatives with the tightening and stringent implementation of the international pollution standards, pollution prevention policies are expected to move in a more material management direction. I argue MLG at firm level emphasize both increasingly coordinated and interaction between organizational actors and increasingly 
important to mobilize resource to achieve a common objective. This study identifies the most common types of multi-level governance is to build focus on sustainable consumption and production, green marketing practices, supplier engagement, environmental management capabilities, management support as means to achieve material flow and reflow in the circular economy system. The successful transition from blue to the green world requires to focus on multi-level governance aimed to achieve zero-pollution targets.

Multi-level governance pursues to develop a more holistic view of governance in shaping the collective orders of organization.MLG arrangements within organization settings will lead to effective solutions to pollution prevention planning and performing better than the competitor's firm. It emphasizes on decentralization and responsiveness to specific environmental challenges, along with the perspective to deploy Intrapreneurship initiatives. MLG means that decision formation process in the organization rest at several different departments. This study argues that to achieve a zero-pollution agenda, pro-active measures need to be implemented within an operational strategy. It imparts opportunities for sustainability initiatives and broader levels of participation of different organizational units that can minimize and correct errors in the management of responsible material sourcing and management. A multi-level governance process helps companies can control pollution prevention. Multi-level governance(MLG), where all resources are tied up in an operational task used to facilitate strategic planning on a zero-waste strategy. This multi-level governance approach provides a sound basis for internal planning and helps firms for design thinking approach to the design process that minimize pollution. Research surrounding pollution prevention strategies and its impact on sustainability performance highlight a growing need to incorporate multi-level governance into their operational strategy. I expect that strategic pollution prevention planning plays an important role in improving the process and product designs by applying novel ideas and meaningfulness to enhance the environmental, economic and social performance. The focus of future research should be to test the supplier engagement relationship and the role of creativity in the strengthening of the relationships.

Figure 3 offers an insight into the issue of the integration of ecological practices to achieve a successful transition towards a green world. The multi-governance frameworks are driving behind the organization moves from blue word to green world Pollution prevention planning is systematic and purposeful use of various practices to successfully transition from blue world to the green world, see Figure 3. Unlike, organizations in the blue world show having a series of sustainability initiatives, but less focus is given on recollection of the material and pollution prevention planning.

\section{Sustainable Pollution prevention Strategies}

The organization should demonstrate customer value to adopt green products and pollution prevention measures.

Prioritize consumer needs and improve marketing mix

Reuse the recovered parts components from the end of life.

Sent the parts components to the local supplier for refabrication or remanufacturing.

Develop environmentally friendly leadership to minimize and prevent pollution

Communicate zero waste strategies to upstream and downstream supply partners.

Strive for the implementation of green marketing strategies 
Develop organizational capabilities to reduce waste.

Sustainable marketing practices can provide guidelines for a waste management issue, dumping and treatment of product and packaging waste.

Regulations that supports standardization of dumping, treatment of storage and waste management awareness to end customers are required to encourage.

The firm may install the circular economy as its major framework for increased growth by focusing on inter-firm clusters at the network level. Collaboration with focal suppliers and customers, therefore, foster the development of circular economic practices, which take sustainability issues.

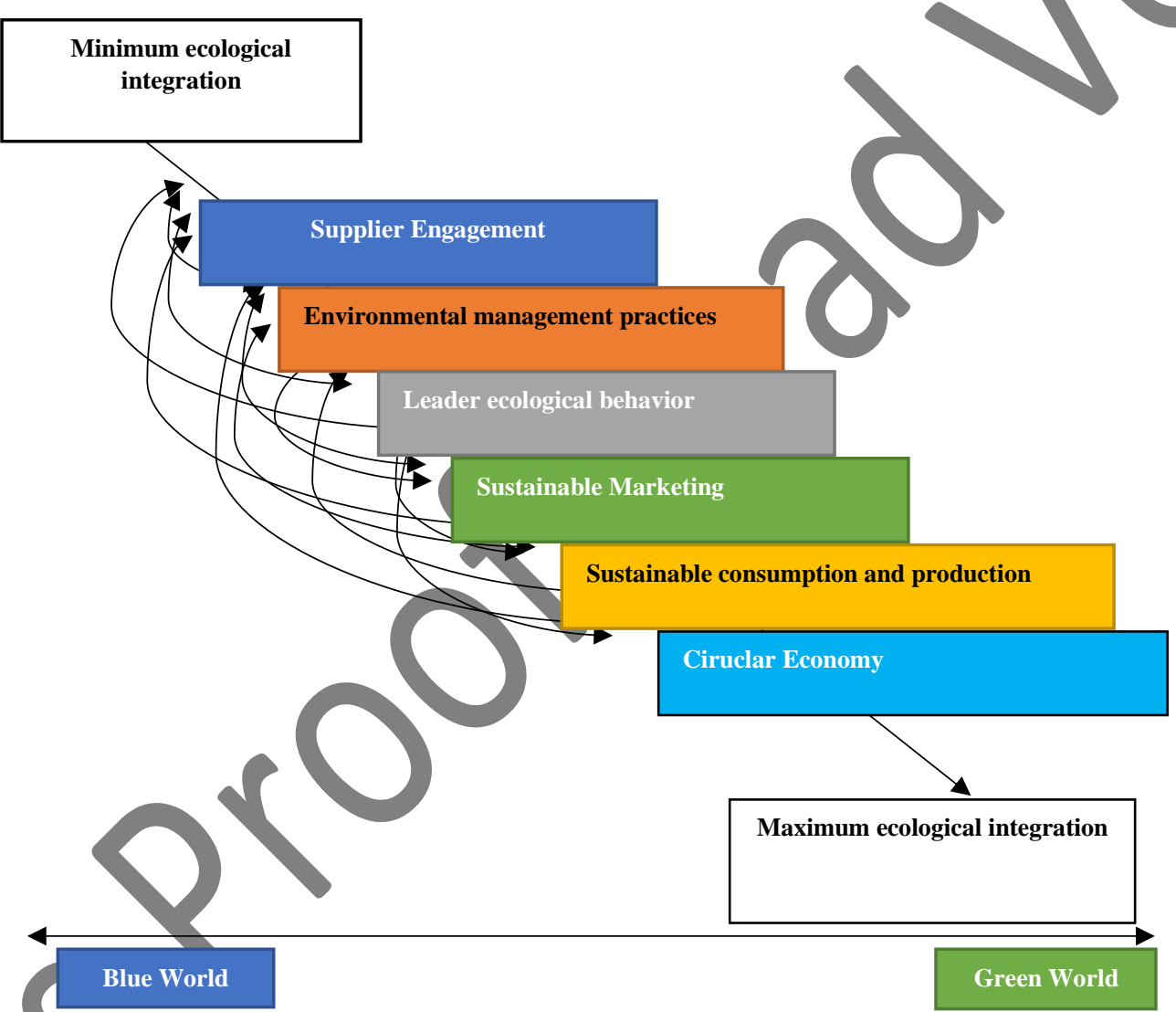

Fig.3 Planning continum from blue world to green world

\section{References}

Ajzen, I., 1991. The theory of planned behaviour. Organ. Behav. Hum. Decis. Process. 50, 179-211.

Antioco, M., Kleijnen, M., 2010. Consumer adoption of technological innovations: Effects of psychological and functional barriers in a lack of content versus a presence of content situation. Eur. J. Mark. 44, $1700-1724$.

Aras, G., Crowther, D., 2009. Corporate sustainability reporting: a study in disingenuity? J. Bus. ethics 87, 279.

Awan, U., 2011. Green Marketing: Marketing Strategies for the Swedish Energy Companies. Int. J. Ind. Mark. 1, 1-19. https://doi.org/10.5296/ijim.v1i2.1008

Awan, U., Abbasi, A.S., 2013. Environmental Sustainability through Determinism the Level of Environmental Awareness, Knowledge and Behavior among Business Graduates. Res. J. Environ. Earth Sci. 5, 505-515. 
Awan, U., Abbasi, A.S., Humayon, A.A., 2014. The Concept of Civic Sustainability is Need of Hour 1. Res. J. Environ. Earth Sci. 6, 347-352.

Awan, Usama, Kraslawski, A., Huiskonen, J., 2018a. A Collaborative Framework for Governance Mechanism and Sustainability Performance in Supply Chain, in: International Conference on Dynamics in Logistics. pp. 67-75.

Awan, Usama, Kraslawski, A., Huiskonen, J., 2018b. The Effects of an Ambidextrous Leadership on the Relationship between Governance Mechanism and Social Sustainability. Procedia - Soc. Behav. Sci. https://doi.org/10.1016/j.sbspro.2018.04.017

Awan, U., Kraslawski, A., Huiskonen, J., 2018. Buyer-supplier relationship on social sustainability: Moderation analysis of cultural intelligence. Cogent Bus. Manag. 5. https://doi.org/10.1080/23311975.2018.1429346

Awan, U., Raza, M.A., 2010. Green Consumer Behavior : Empirical Study of Swedish Consumer Behavior Department of Management Sciences. Recent Res. Econ. 89-104.

Bae, H.S., 2017. The Asian Journal of Shipping and Logistics The Effect of Environmental Capabilities on Environmental Strategy and Environmental Performance of Korean Exporters for Green Supply Chain Management *. Asian J. Shipp. Logist. 33, 167-176. https://doi.org/10.1016/j.ajs1.2017.09.006

Bai, X., Chang, J., 2015. Corporate social responsibility and firm performance: The mediating role of marketing competence and the moderating role of market environment. Asia Pacific J. Manag. 32, 505-530.

Bocken, N.M.P., de Pauw, I., Bakker, C., van der Grinten, B., 2016. Product design and business model strategies for a circular economy. J. Ind. Prod. Eng. 33, 308-320.

Boiral, O., 2006. Global Warming: Should Companies Adopt a Proactive Strategy? Long Range Plann. 39, 315-330. https://doi.org/10.1016/j.lrp.2006.07.002

Brundtland, G.H., Others, 1987. Our common future: Report of the 1987 World Commission on Environment and Development. United Nations, Oslo 1-59.

Carballo-Penela, A., Doménech, J.L., 2010. Managing the carbon footprint of products: the contribution of the method composed of financial statements (MC3). Int. J Life Cycle Assess. 15, 962-969.

Carter, C.R., Rogers, D.S., 2008. A framework of sustainable supply chain management: moving toward new theory. Int. J. Phys. Distrib. Logist. Manag. 38, 360-387.

Chabowski, B.R., Mena, J.A., Gonzalez-Padron, T.L., 2011. The structure of sustainability research in marketing, 1958-2008: A basis for future research opportunities. J. Acad. Mark. Sci. 39, 55-70. https://doi.org/10.1007/s11747-010-0212-7

Dangelico, R.M., Pujari, D., 2010. Mainstreaming green product innovation: Why and how companies integrate environmental sustainability. J. Bus. ethics 95, 471-486.

Deif, A.M., 2011. A system model for green manufacturing. J. Clean. Prod. 19, 1553-1559. https://doi.org/10.1016/j.jclepro.2011.05.022

Elkington, J., 1997. Cannibals with forks. triple bottom line 21 st century.

European Commision, 2012. Roadmap 2050. Policy 1-9. https://doi.org/10.2833/10759

European Commission, 2007. EACH in Brief. Environment Directorate General, European Commission. Brussels, Belgium.

European Commission, 2008., 2008. Directive 2008/98/EC of the European Parliament and of the Council of 19 November 2008 on Waste and Repealing Certain Directives. [WWW Document].

Fehr, R., Yam, K.C.S., Dang, C., 2015. Moralized leadership: The construction and consequences of ethical leader perceptions. Acad. Manag. Rev. 40, 182-209.

Formentini, M., Taticchi, P., 2016. Corporate sustainability approaches and governance mechanisms in sustainable supply chain management. J. Clean. Prod. 112, 1920-1933.

https.//doi.org/10.1016/j.jclepro.2014.12.072

Gatersleben, B., Vlek, C., 1998. Household consumption, quality of life, and environmental impacts: A psychological perspective and empirical study. Green households? Domest. Consum. Environ. Sustain. $141-183$.

Gonçalves, G., Gonçalves, G., Reis, M., Reis, M., Sousa, C., Sousa, C., Santos, J., Santos, J., Orgamb\$\$\$ \$ $\$$ idez-Ramos, A., Orgamb\$\$\$ $\$ 1$ idez-Ramos, A., Others, 2016. Cultural intelligence and conflict management styles. Int. J. Organ. Anal. 24, 725-742.

Groenewald, J., Grandjean, T., Marco, J., 2017. Accelerated energy capacity measurement of lithium-ion cells to support future circular economy strategies for electric vehicles. Renew. Sustain. Energy Rev. 69, 98-111. https://doi.org/10.1016/j.rser.2016.11.017

Guide, V.D.R., Harrison, T.P., Van Wassenhove, L.N., 2003. The challenge of closed-loop supply chains. Interfaces (Providence). 33, 3-6.

Jackson, S.E., Seo, J., 2010. The greening of strategic HRM scholarship. Organ. Manag. J. 7, 278-290.

Jiang, L., Lin, C., Lin, P., 2014. The determinants of pollution levels : Firm-level evidence from Chinese 
manufacturing. J. Comp. Econ. 42, 118-142. https://doi.org/10.1016/j.jce.2013.07.007

Kaiser, F.G., Hübner, G., Bogner, F.X., 2005. Contrasting the Theory of Planned Behavior with the ValueBelief-Norm Model in Explaining Conservation Behavior 1. J. Appl. Soc. Psychol. 35, 2150-2170.

Karlsson, R., Luttropp, C., 2006. EcoDesign: what's happening? An overview of the subject area of EcoDesign and of the papers in this special issue. J. Clean. Prod. 14, 1291-1298.

Kenneth W. Green Jr., Zelbst, P.J., Meacham, J., Bhadauria, V.S., 2012. Green supply chain management practices: impact on performance. Supply Chain Manag. An Int. J. 17, 290-305. https://doi.org/10.1108/13598541211227126

Kirchherr, J., Reike, D., Hekkert, M., 2017. Conceptualizing the circular economy: An analysis of 114 definitions. Resour. Conserv. Recycl. 127, 221-232. https://doi.org/10.1016/j.resconrec.2017.09.00

Kleijnen, M., Lee, N., Wetzels, M., 2009. An exploration of consumer resistance to innovation and its antecedents. J. Econ. Psychol. 30, 344-357.

Korhonen, J., Honkasalo, A., Seppälä, J., 2018. Circular Economy: The Concept and its Limitations. Ecol. Econ. 143, 37-46. https://doi.org/10.1016/j.ecolecon.2017.06.041

Kumar, D., Rahman, Z., 2016. Buyer supplier relationship and supply chain sustainability: empirical study of Indian automobile industry. J. Clean. Prod. 131, 836-848.

Kumar, S., 2016. No TitPollution causes 4,400 deaths a year in Pakistanle.

Lambert, D.M., Cooper, M.C., Pagh, J.D., 1998. Supply Chain Management: Implementation Issues and Research Opportunities, The International Journal of Logistics Management. https://doi.org/10.1108/09574099810805807

Landrigan, P.J., Fuller, R., Acosta, N.J.R., Adeyi, O., Arnold, R., Baldé, A.B., Bertollini, R., Bose-O’Reilly, S., Boufford, J.I., Breysse, P.N., others, 2018. The Lancet Commission on pollution and health. Lancet 391, 462-512.

Landrigan, P.J., Fuller, R., Fisher, S., Suk, W.A., Sly, P., Chiles, T.C., Reilly, S.B., 2019. Pollution and children 's health. Sci. Total Environ. 650, 2389-2394. https://doi.org/10.1016/j.scitotenv.2018.09.375

Landrigan, P.J., Goldman, L.R., 2011. Children's vulnerability to toxic chemicals: a challenge and opportunity to strengthen health and environmental policy. Health Aff. 30, 842-850.

León-Bravo, V., Caniato, F., Caridi, M., Johnsen, T., 2017. Collaboration for Sustainability in the Food Supply Chain: A Multi-Stage Study in Italy. Sustainability 9, 1253.

Leonidou, C.N., Katsikeas, C.S., Morgan, N.A., 2013. "Greening" the marketing mix: Do firms do it and does it pay off? J. Acad. Mark. Sci. 41, 151-170.

Leppelt, T., Foerstl, K., Reuter, C., Hartmann, E., 2013. Sustainability management beyond organizational boundaries-sustainable supplier relationship management in the chemical industry. J. Clean. Prod. 56, 94-102. https://doi.org/10.1016/j.jclepro.2011.10.011

Li, Y., Cui, V., Liu, H., 2017. Dyadic specific investments, absorptive capacity, and manufacturers' market knowledge acquisition: Evidence from manufacturer--distributor dyads. J. Bus. Res. 78, 323-331.

Linton, J.D., Klassen, R., Jayaraman, V., 2007. Sustainable supply chains: An introduction. J. Oper. Manag. $25,1075-1082$.

Lu, F., Xu, D., Cheng, Y., Dong, S., Guo, C., Jiang, X., Zheng, X., 2015. Systematic review and metaanalysis of the adverse health effects of ambient PM 2.5 and PM 10 pollution in the Chinese population. Environ. Res. 136, 196-204.

Mani, V., Gunasekaran, A., Delgado, C., 2018. Enhancing supply chain performance through supplier social sustainability: An emerging economy perspective. Int. J. Prod. Econ. 195, 259-272. https://doi.org/10.1016/j.ijpe.2017.10.025

Meinlschmidt, J., Foerstl, K., Kirchoff, J.F., 2016. The role of absorptive and desorptive capacity (ACDC) in sustainable supply management: A longitudinal analysis. Int. J. Phys. Distrib. Logist. Manag. 46, 177211.

Menon, Ajay, Menon, Anil, 1997. Enviropreneurial marketing strategy: the emergence of corporate environmentalism as market strategy. J. Mark. 61, 51-67.

Modi, S.B., Mabert, V.A., 2007. Supplier development: Improving supplier performance through knowledge transfer. J. Oper. Manag. 25, 42-64.

Murray, A., Skene, K., Haynes, K., 2017. The Circular Economy: An Interdisciplinary Exploration of the Concept and Application in a Global Context. J. Bus. Ethics 140, 369-380. https://doi.org/10.1007/s10551-015-2693-2

Murray, R., 2002. Zero Waste Greenpeace Environmental Trust, London, UK.

Nyrud, A.Q., Roos, A., Sande, J.B., 2008. Residential bioenergy heating: A study of consumer perceptions of improved woodstoves. Energy Policy 36, 3169-3176.

Ones, D.S., Dilchert, S., 2012. Environmental sustainability at work: A call to action. Ind. Organ. Psychol. 5, 444-466.

Parmigiani, A., Klassen, R.D., Russo, M. V, 2011. Efficiency meets accountability: Performance 
implications of supply chain configuration, control, and capabilities. J. Oper. Manag. 29, 212-223. https://doi.org/10.1016/j.jom.2011.01.001

Peattie, K., Belz, F.-M., 2010. Sustainability marketing-An innovative conception of marketing. Mark. Rev. St. Gall. 27, 8-15.

Podsakoff, N.P., Podsakoff, P.M., MacKenzie, S.B., Maynes, T.D., Spoelma, T.M., 2014. Consequences of unit-level organizational citizenship behaviors: A review and recommendations for future research. J. Organ. Behav. 35, S87--S119.

Polonsky, M.J., Rosenberger III, P.J., 2001. Reevaluating green marketing: a strategic approach. Bus. Horiz. 44, 21-30.

Porter, M.E., 2011. Competitive advantage of nations: creating and sustaining superior performance. Simon and Schuster.

Reuter, C., Foerstl, K.A.I., Hartmann, E.V.I., Blome, C., 2010. Sustainable global supplier management: the role of dynamic capabilities in achieving competitive advantage. J. Supply Chain Manag. 46, 45-63.

Roy, M., 1992. Pollution prevention, organizational culture, and social learning. Envtl. L. 22, 189.

Russell, S., Griffiths, A., 2008. The role of emotions in driving workplace pro-environmental behaviors, in: Emotions, Ethics and Decision-Making. Emerald Group Publishing Limited, pp. 83-107.

Sancha, C., Gimenez, C., Sierra, V., 2016a. Achieving a socially responsible sapply chain through assessment and collaboration. J. Clean. Prod. 112, 1934-1947.

Sancha, C., Gimenez, C., Sierra, V., Kazeminia, A., 2015. Does implementing social supplier development practices pay off? Supply Chain Manag. An Int. J. 20, 389-403.

Sancha, C., Wong, C.W.Y., Thomsen, C.G., 2016b. Buyer--supplier relationships on environmental issues: a contingency perspective. J. Clean. Prod. 112, 1849-1860.

Saunders, L.W., Kleiner, B.M., McCoy, A.P., Lingard, H., Mills, T., Blismas, N., Wakefield, R., 2015. The effect of early supplier engagement on social sustainability outcomes in project-based supply chains. J. Purch. Supply Manag. 21, 285-295. https://doi.org/10.1016/j.pursup.2015.05.004

Sousa-Zomer, T.T., Magalhães, L., Zancul, E., Cauchick-Miguel, P.A., 2017. Exploring the challenges for circular business implementation in manufacturing companies: An empirical investigation of a payper-use service provider. Resour. Conserv. Recycl. 135, 3-13. https://doi.org/10.1016/j.resconrec.2017.10.033

Sprotles, G.B., Kendall, E.L., 1986. A methodology for profiling consumers' decision-making styles. J. Consum. Aff. 20, 267-279.

Tang, C.S., 2008. Making products safe: process and challenges. Int. Commer. Rev. 8, 48-55.

United States Environmental Protection Agency., 1992. Environmental Equity: Reducing Risk for All Communities: Report. US Environmental Protection Agency, Office of Policy, Planning and Evaluation.

Vinodh, S., Girubha, R.J., 2012.PROMETHEE based sustainable concept selection. Appl. Math. Model. 36, 5301-5308.

Wagner, S.M., 2010. Indirect and direct supplier development: performance implications of individual and combined effects. IEEE Trans. Eng. Manag. 57, 536-546.

Zeng, X., Li, J., Singh, N., 2014. Recycling of Spent Lithium-Ion Battery : A Critical Review 3389. https://doi.org/10.1080/10643389.2013.763578

Zhang, D., Liu, J., Li, B., 2014. Tackling air pollution in China-What do we learn from the great smog of 1950s in London. Sustainability 6, 5322-5338.

Zhang, J.J., Samet, J.M., 2015. Chinese haze versus Western smog: lessons learned. J. Thorac. Dis. $7,3$.

Zibarras, L., Ballinger, C., 2011. Promoting environmental behaviour in the workplace: A survey of UK organisations. Going green Psychol. Sustain. Work. 84-90.

Zubi, G., Dufo-López, R., Carvalho, M., Pasaoglu, G., 2018. The lithium-ion battery: State of the art and future perspectives. Renew. Sustain. Energy Rev. 89, 292-308.

https://doi.org/10.1016/j.rser.2018.03.002 